\title{
Yellow Nail Syndrome - a Case Report
}

\author{
Mirjana PARAVINA ${ }^{1 *}$, Ivana BINIĆ ${ }^{1,2}$, \\ Danijela POPOVIĆ ${ }^{1,2}$, Dragana LJUBISAVLJEVIĆ ${ }^{2}$ \\ ${ }^{1}$ Medical Faculty, University of Niš, Serbia \\ ${ }^{2}$ Clinic of Skin and Venereal Diseases, Clinical Center of Nišs, Serbia \\ *Correspondence: Mirjana Paravina, E-mail: mirjanaparavina@gmail.com
}

UDK 616.596:616.718-005.9]-08

UDK 616.596:616.2-036.1]-08

\section{DE GRUYTER OPEN}

\begin{abstract}
Yellow nail syndrome is a rare disease of unknown etiology. It is clinically characterized by a triad of yellow nails, lymphedema at one or more sites, and chronic respiratory disease (bronchitis, bronchiectasis and rhinosinusitis). All nails may be affected, but some may be spared. The nail plates are yellowish green, thickened, occasionally with transverse ridging and onycholysis, with increased longitudinal and transversal over-curvature, with partial or complete separation of the nail plate from the nail bed, without lunula and cuticle and slow nail growth rate. The lymphedema is usually peripheral, affecting the lower limbs, or in the form of pleural effusion.

This is a case report of a 47-year-old female patient who presented with nail changes at the age of 40; two years later the patient developed lymphedema of the lower limbs, and a year later a chronic respiratory disease. The affected nails were yellow to yellow-gray, with thickened nail plates separated from the nail bed, ingrown in the perionychium, without lunula. At the same time, additional examinations revealed the following associated conditions: edema of talocrural joints in both legs, chronic obstructive bronchitis, bronchial asthma, chronic rhinitis with bilateral nasal polyposis, labile arterial hypertension. Apart from the management of chronic respiratory disease, oral vitamin E capsules (200 mg 3 times a day) and topical vitamin E solution were administered over 15 months. The nails began to grow, and the newly grown nails were of normal pigmentation.

In conclusion, we present a case of an adult female patient with yellow nail syndrome, and a recognized association of peripheral edema and chronic pulmonary disease. The patient had a typical clinical picture, all the nails were affected, but showed a favorable response to systemic and topical vitamin $E$ therapy.
\end{abstract}

\section{Key words}

Yellow Nail Syndrome; Lymphedema; Bronchitis, Chronic; Asthma; Vitamin E; Treatment Outcome; Case Reports

Y ellow nail syndrome (YNS) is a rare disease of unknown etiology (1). The term YNS was first described by Samman and White in 1964 (2). They reported a group of 13 patients with lymphedema of the lower extremities and yellow nails. In 1966 (3), Emerson described a patient with a pleural effusion. All nails may be affected, but some may be spared (4). Although there are data claiming that only two groups of symptoms appear in $1 / 3$ of cases (3), the typical clinical picture of YNS $(5,6)$ is characterized by a triad of yellow nails, lymphedema at one or more sites, and chronic respiratory disease (bronchitis, bronchiectasis and rhinosinusitis) (7 - 12).
The disorder is characterized by discoloration of nail plates which varies from light brown, dark yellow, yellow and green, with thickening, occasionally with transverse ridging and onycholysis, increased longitudinal and transversal over-curvature, partial or complete separation of the nail plate from the nail bed, without lunula and cuticle, with slow nail growth rate $(13-16)$.

The lymphedema is mostly peripheral (lower limbs or hands), or affects the face, larynx, with pleural effusion and ascites, and occasionally it is universal (17). In some cases the edema has been shown to be due to abnormalities of the lymphatics, either atresia 
or varicosity. Other cases have normal lymphatics, indicating that a functional rather than an anatomical defect may be present, or only the smallest lymph vessels are defective (4).

Respiratory disorders include: sinusitis, recurrent pneumonia, chronic bronchitis, bronchiectasis, pleural effusion (18).

It is believed that YNS is caused by lymphatic abnormalities, either anatomical (found only in a minority of patients with congenital abnormalities), or functional, with increased microvascular permeability (19). A dense fibrous tissue has been found in the nail bed and matrix, replacing subungual stroma with scattered ectatic vessels; obstruction of lymphatics by this dense stroma may be responsible for the abnormal lymphatic function found in the affected digits in some but not all cases (4). Reduced lymphatic drainage may cause peripheral edema or pleural effusion $(13,16)$.

\section{Case report}

The case history of a 47-year-old female textile worker shows that she presented with nail changes at the age of 40. Her nails stopped growing and became dark in color. Antifungal therapy provided some improvement. Two years later, at the age of 42 , she had pneumonia and since the age of 43 she suffers from chronic obstructive bronchitis. She also developed edema of both legs, expressed especially in the morning, followed by numbness of fingers. Since the age of 45 , in the last two years, all her nails have been discolored, yellow to yellow-gray, thickened, ingrown, painful, and almost stopped growing. Due to leg edema she was treated at the Institute of Rheumatology in Belgrade with the diagnosis: polyarthralgia and edema of talocrural joints of both legs. Her family history was negative.

\section{Physical examination}

Skin examination showed yellowish to gray nails; the nail plates were thickened, separated from the nail bed, without lunula and cuticle, laterally ingrown in the perionychium (tweezer look), accompanied by pain (Figures 1 and 2). Lower extremities, ankles and feet were affected with edema: elastic edema, without skin discoloration (Figure 3).

\section{Laboratory and other test results}

The relevant laboratory test results were within reference values.

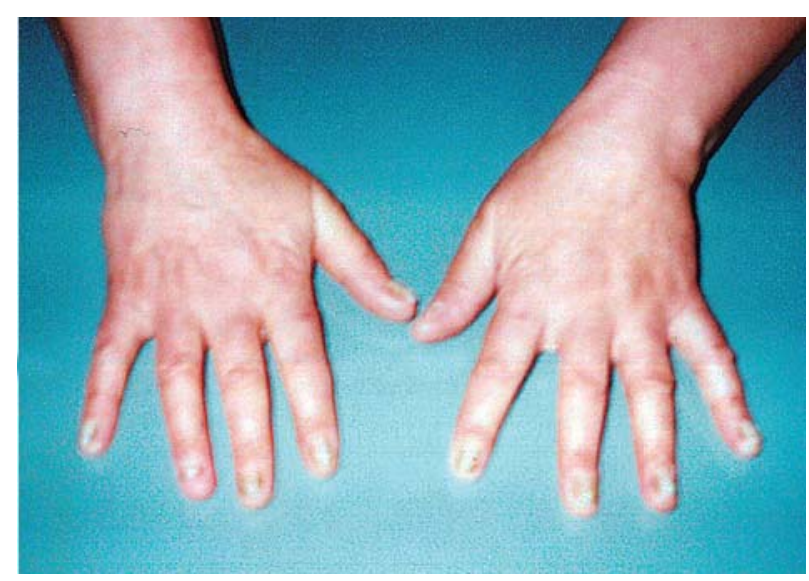

Figure 1. Prior therapy: fingernails are yellow to yellowish-gray, nail plates are thickened, separated from the nail bed, without lunula

Color Duplex Doppler ultrasound findings of the lower limb veins and arteries were within the normal range. Chest and heart X-ray: slightly prominent bilateral hilar-basal shadows; the cardiac silhouette was normal in size and contour.

Spirometry - spirogram: mild obstructive pulmonary insufficiency.

Bronchial provocation test with methacholine: negative.

Pulmonary perfusion scintigraphy: no clear scintigraphic signs of perfusion abnormalities.

Skin prick testing to aeroallergens: positive to grass pollen and textile dust.

Pulmonary findings - diagnosis: chronic obstructive bronchitis, bronchial asthma.

ENT findings - diagnosis: chronic rhinitis,

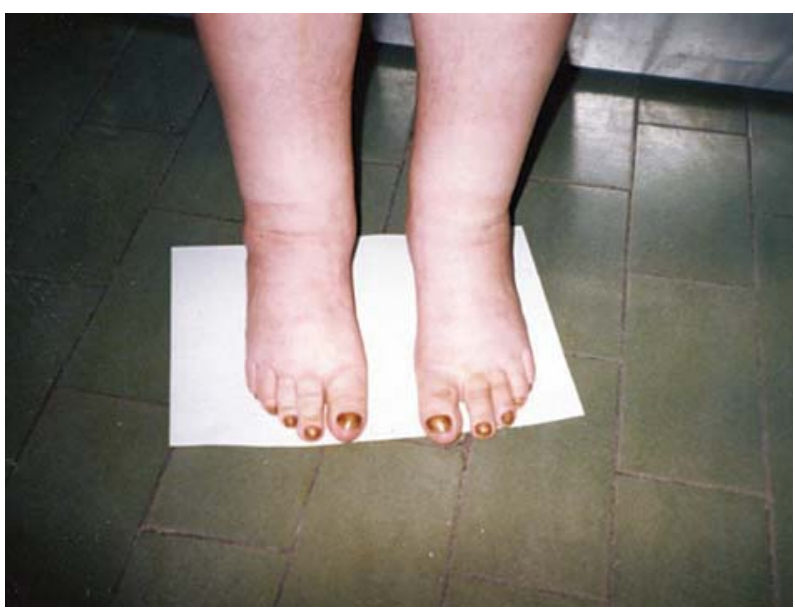

Figure 2. Prior therapy: nail plates of toenails are dark yellow and thickened 


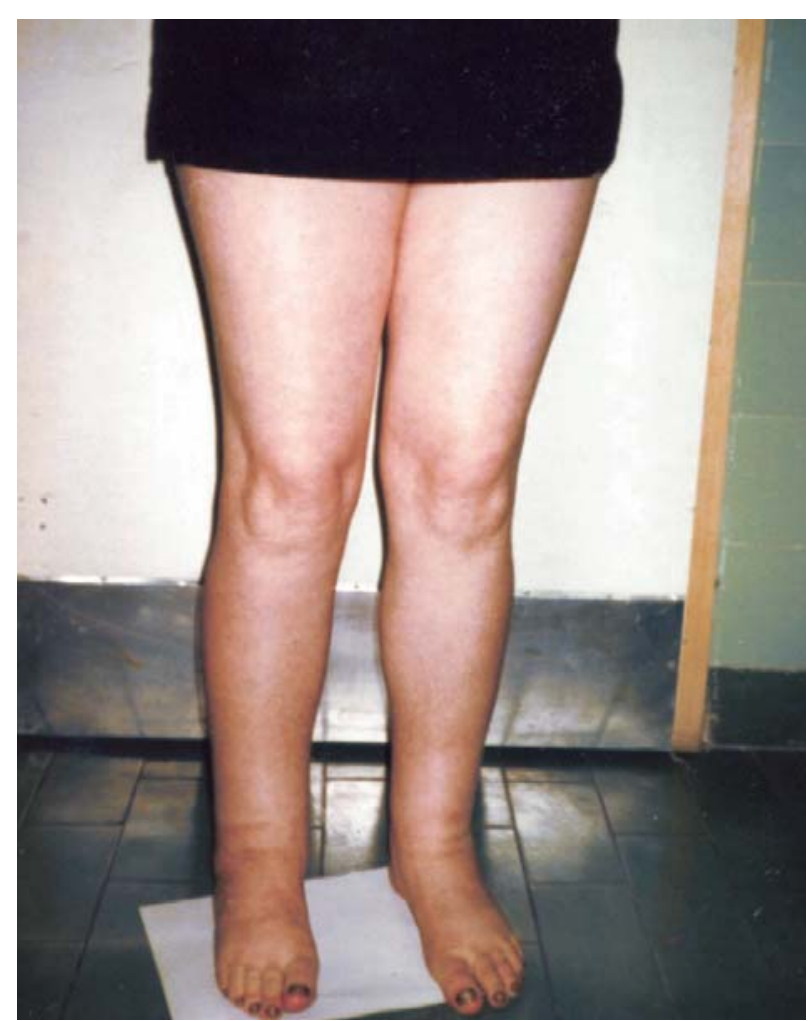

Figure 3. Prior therapy: edema of the lower legs, ankles and feet

bilateral nasal polyposis, bilateral cochlear nerve lesions.

Ophthalmology findings - diagnosis: traumatic cataract of the left eye, concomitant strabismus.

Cardiovascular examination - diagnosis: labile arterial hypertension.

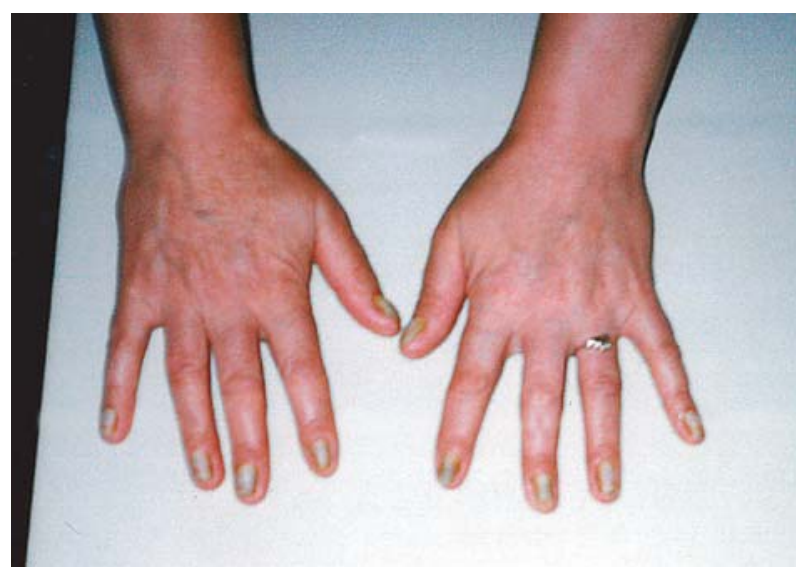

Figure 4. After 15 months of therapy: nail plates of fingernails with discoloration, separated from the nail bed, yellowish in the distal parts, the proximal parts of normal appearance

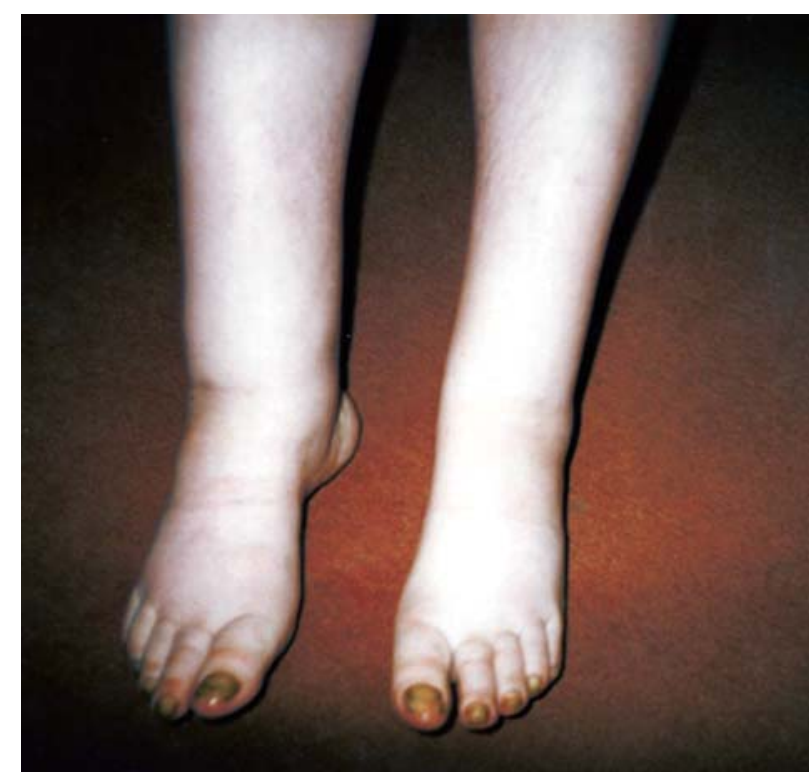

Figure 5. After 15 months of therapy: nail plates of toenails are thickened, yellowish-brown in the distal parts

\section{Therapy}

In addition to the medications prescribed by the pulmologist and cardiologist, vitamin E capsules (200 mg 3 times a day), topical vitamin $\mathrm{E}$ solution, and $\mathrm{AD}$ drops were initiated. Several months later, the treatment showed improvement: the nails started growing, the

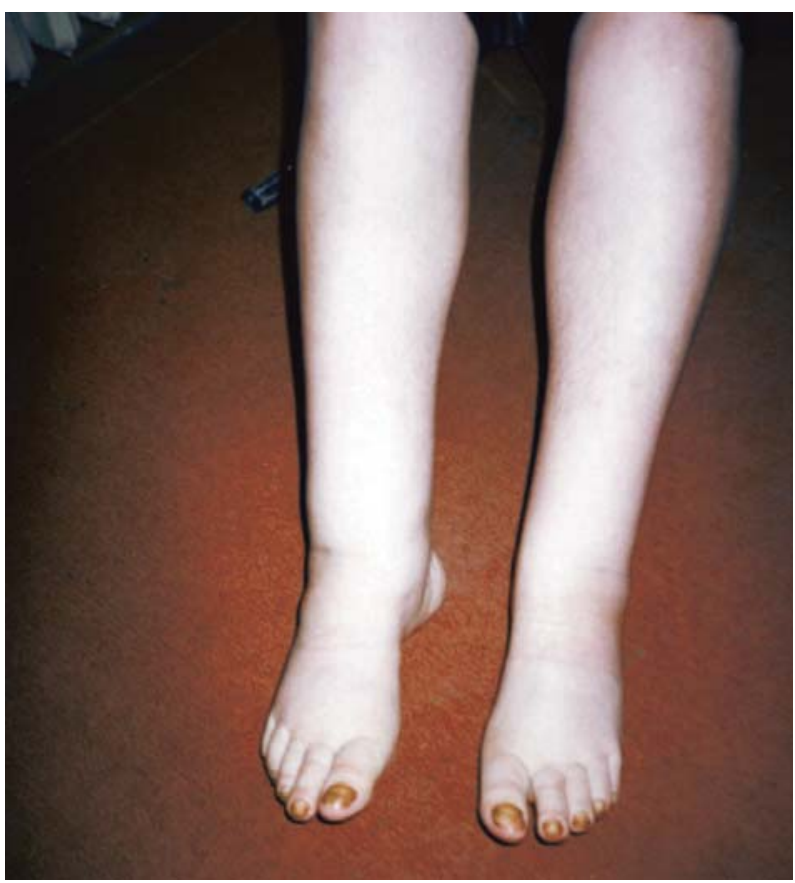

Figure 6. After 15 months of therapy: lower legs, ankles and feet are swollen, affected by lymphedema 
proximal parts of nail plates were of normal color, and the lunula became visible.

On follow-up examination, after 15 months of treatment, the nail plates on the hands were yellowish in the distal portion, from 1 to several millimeters (Figure 4). The toenail plates were thickened, yellowish-brown in the distal portion, from $1 \mathrm{~mm}$ to involvement of the whole thumb nail plate; the proximal nail plates were normal (Figure 5); the lower legs, ankles and feet were swollen, affected by lymphedema (Figure 6).

\section{Discussion}

According to the literature data, up to 2004, there were 150 case reports on YNS (17), by 2014, about 200 cases were described (1), confirming that it is an extremely rare disease.

The syndrome affects all age groups: from birth to old age $(20,21,22)$ : Valdés et al. reviewed reports on 150 patients aged 0 to 88 years, with a median age of 60 years (range from 41 to 80 years) (12). The literature data show that the disorder is more common in females, with a female to male ration of $1.6: 1(10,23,24)$. In their study, Valdés et al. reported a male to female ratio of $1.2: 1$ (12). According to the world literature, only a small number of reports have been published on YNS in children $(8,25-28)$; congenital cases have been reported as well $(28,29)$.

According to Valdés and associates (12), lymphedema was observed in all patients, nail discoloration in $85.6 \%$, and pleural effusion in $68.3 \%$, while other authors claim that nail discoloration was registered in $89 \%$ of patients, lymphedema in $80 \%$, and respiratory disease in a $63 \%(25,28,30)$. There is a case report of a girl with lymphedema and pleural effusion, without nail discoloration (8), a boy only with nail discoloration (28), and a female patient who had yellow nails since childhood, without lymphedema, who postpartum developed a massive pleural effusion (21). Our patient exhibited a clinical triad of nail discoloration, lymphedema, and a respiratory disease. Nail discolorations may precede other symptoms, as in our case, may appear at the same time, or later (14). All nails are affected only in $10 \%$ of cases (9). The nail growth is always slow, 0.1 to $0.25 \mathrm{~mm}$ per week, instead of 0.5 to $2 \mathrm{~mm}$ per week $(4,14)$. In our patient nail discoloration started before other manifestations of the triad, but it fully developed later.
There are opinions that YNS is ahereditary disorder, transmitted in an autosomal dominant fashion (31). Although congenital hypoplasia of the lymphatics plays an important role in the clinical picture (10), in a series of 150 patients (12), familial YNS was registered only in 9 patients. Due to low incidence of familial cases (32), it has generally been accepted that YNS is not primarily a genetic, but a sporadic (20), acquired disorder (16). It may be idiopathic or secondary to systemic diseases, or a result of adverse drug effects $(6,33)$. The pathology of YNS is not known (28). Firstly, hypoplastic or deficient lymphatic vessels have been postulated as the cause; it has been hypothesized that the clinical manifestations of YNS are the result of primary stromal sclerosis, which may lead to lymphatic obstruction. Lymphangiography has demonstrated anatomic defects in both the number and size of the lymphatic vasculature of some, but not all patients, as mentioned before. The reversibility of YNS and the lack of demonstrable anatomic defects in some patients suggest that the underlying cause of this condition may be a functional rather than an anatomic abnormality. It is assumed that the respiratory component of the disease is caused either by lymphatic system hypoplasia or the immune deficiency (34). YNS can be associated with combined immune deficiency, which may be responsible for associated sinopulmonary infections manifestations (20).

YNS has been associated with a variety of diseases (17). The most common conditions associated with YNS include malignant diseases - melanoma (3), bronchogenic carcinoma (35), thoracic carcinoma (36) renal cell carcinoma (37); lymphproliferative diseases (38, 39); immune deficiency conditions (39), acquired immunodeficiency syndrome (40); endocrine diseases (25, 40, 41, 42); connective tissue diseases $(10,43,44)$; obstructive sleep apnea (45); xanthogranulomatous pyelonephritis (46), nephrotic syndrome (47), membranous glomerulonephritis (24), tuberculosis (48) post-myocardial infarction (49), pericardial effusion (50), asthma (42). YNS has been reported after treatment with sodium valproate, D-penicillamine (51), and gold sodium thiomalate in the treatment of rheumatoid arthritis (52).

Valdés and associates (12) studied reports of 150 patients, out of which 14 presented with malignancy. There are opinions that YNS should be examined in terms of neoplasia (52), even some claiming that it is a paraneoplastic disease (53). 
Clues to diagnosis are the presence of dystrophic, yellowish nails, peripheral lymphedema and pleural effusions (54). Nail changes are of greatest diagnostic significance; they should be distinguished from changes found in lichen planus, which is not associated with systemic symptoms, whereas changes on the nail plates are characteristically followed by atrophy (especially visible on the nails on the hands), which is not the case in YNS (4). Some authors believe that the appearance of yellow nails in hypothyroidism and in acquired immune deficiency syndrome (AIDS) is solely the result of slow nail growth (40). Differential diagnosis should include systemic edemas, as well as long-term pleural effusions in patients with bronchiectasis and sinusitis (54).

Apart from adequate treatment of recurrent infections, pleural effusion and associated diseases, André (55) recommends the following treatment of nail changes: intradermal triamcinolone acetonide injections, topical application of vitamin $\mathrm{E}$ in DMSO (dimethyl sulphoxide), oral vitamin E - 400 - $800 \mathrm{IU} /$ day during 18 months, and zinc sulphate - $300 \mathrm{mg} /$ day for 2 years, in combination with antimycotics, if necessary (55). Itraconazole increases the longitudinal growth rate of nail plates (4). The combination of vitamin $\mathrm{E}$ and antimycotics, (itraconazole or fluconazole) in secondary infection, has led to significant improvement. Douri (29) also reported about beneficial effects of vitamin $\mathrm{E}$ in the treatment of this disorder. After 6 months of treatment with vitamin E solution, Lambert reported an improvement of fingernail growth rate, but not significant compared to placebo (28). The assumed mechanisms of favorable effects of vitamin $\mathrm{E}$ are based on its antioxidant effects in vivo, which play an important role in cell membranes protection from oxidative damage by free radicals, in blocking the production of yellow pigment lipofuscin (pigment resulting from lipid oxidation of free radicals, causing different degrees of yellow color in tissues) and in prevention of the DNA and other cellular proteins damage, which may disturb the keratinization process and decrease the growth rate of nails (56).

Our patient presented with a classic triad of YNS: yellow nails, lymphedema and respiratory disorders. The first changes appeared on the nails, then respiratory disorders, and finally lymphedema. After consulting a pulmonologist, she received treatment for respiratory problems. Topical and oral vitamin E therapy resulted in improvement in terms of nail growth rate without yellow discoloration.

The course of the disease is generally benign, and clinical manifestations are usually managed with the above mentioned therapy (17). Spontaneous improvement of nail discoloration is reported in up to $30 \%$ of cases $(6,46)$.

\section{Conclusion}

We report a rare case of yellow nail syndrome where all the nails were affected, with a recognized association with chronic pulmonary disease and edema of the legs, and favorable response to systemic and topical vitamin E treatment.

\section{References}

1. Hassan K. Yellow nail syndrome: a case report. Zanco J Med Sci 2014;18(1):680-2.

2. Samman PD, White WF. The "Yellow Nail" syndrome. Br J Dermatol 1964;76:153-7.

3. Emerson P. Yellow nails, lymphoedema, and pleural effusions. Thorax 1966;21:247-53.

4. de Berker DAR, Baran R. Disorders of nails. In: Burns T, Breathnach S, Cox N, Griffiths C, editors. Rook's textbook of dermatology. $6^{\text {th }}$ ed. Oxford: Blackwell Publishing; 2010. p. 65.1-65.57.

5. Nag A, Mondal S, Banerjee A, Halder S, Sinha D, Chakraborty A, et al. Yellow nail syndrome - report of a classical case from Eastern India. Int J Health Sci Res 2014;4(3):265-8.

6. Saeed RR, Mustafa HM. A 24 year-old male with yellow nail syndrome having bronchiactasis without pleural effusion as a pulmonary manifestation. Indian J Med Sci 2013;67(7):184-7.

7. Cordasco EM, Jr, Beder S, Coltro A, Bavbek S, Gurses H, Mehta AC. Clinical features of the yellow nail syndrome. Cleve Clin J Med 1990;57(5):472-6.

8. Yalcin E, Dogru D, Gonc EN, Cetinkaya A, Kiper N. Yellow nail syndrome in an infant presenting with lymphedema of the eyelids and pleural effusion. Clin Pediatr 2004;43:569-72.

9. Machado RF, Rosa DJ, Leite CC, Neto MP, Gamonai A. Yellow syndrome: case report. An Bras Dermatol 2009;84(6):659-62.

10.Brzezinski P, Bury M, Jagiello-Wieczorek E. Coexistence yellow nail syndrome with systemic symptoms - presentation of cases. N Dermatol Online 2010;1(2):15-8.

11.Letheulle J, Deslee G, Guy T, Lebargy F, Jego P, Delaval P, et al. Le syndrome des ongles jaunes: presentation de cinq cas. Rev Med Respir 2012;29(3):419-25.

12. Valdés L, Huggins JT, Gude F, Ferreiro L, Alvarez-Dobano JM, Golpe A, et al. Characteristics of patients with yellow nail syndrome and pleural effusion. Respirology 2014;19:985-92.

13. Bull RH, Fenton DA, Mortimer PS. Lymphatic function in the yellow nail syndrome. Br J Dermatol 1996;134:307-12.

14.Habif TP. Clinical dermatology. St Louis: Mosby-Year Book Inc; 1996. 
15.Fawcett RS, Linford S, Stulberg DI. Nail abnormalities: clues to systemic disease. Am Fam Physician 2004;69:1417-24.

16. Hoque SR, Mansour S, Mortimer PS. Yellow nail syndrome: not a genetic disorder? Eleven new cases and review of the literature. Br J Dermatol 2007;156:1230-4.

17.Maldonado F, Ryu JH. Yellow nail syndrome. Curr Opin Pulm Med 2009;15:371-5.

18. Maldonado F, Tazelaar HD, Wang CW, Ryu JH. Yellow nail syndrome: analysis of 41 consecutive patients. Chest 2008;134:375-81.

19.D Allessandro A, Muzi G, Monaco A, Filiberto S, Barboni A, Abbritti G. Yellow nail syndrome: does protein leakage play a role? Eur Resp J 2001;17:149-52.

20.Gupta S, Samra D, Agrawal S. T and B cell deficiency associated with yellow nail syndrome. Scand J Immunol 2012;75:329-35.

21.Gunbatar H, Sertogullarindan B, Ekin S, Arisoy A, Ozkol HU. Yellow nail syndrome presenting with postpartum massive pleural effusion. Clin Respir J 2014;8:369-71.

22.Papaiordanou F, Epstein MG, Miayaoka MY, Yang JJH, Pires MC. Unusual manifestation of the yellow nail syndrome - case report. An Bras Dermatol 2014;89(3):490-2.

23. Cohen M, Sahn SA. Bronchiectasis in systemic disease. Chest 1999;116:1063-74.

24.Modrzewska K, Fijotek J, Ptak J, Wiatr E. Yellow nail syndrome in an patient with membranous glomerulonephritis. Pneumonol Alergol Pol 2012;80(2):158-62.

25. Nordkild P, Kromann-Andersen H, Struve-Christensen E. Yellow nail syndrome - the triad of yellow nails, lymphedema, and pleural effusions. Acta Med Scand 1986;219:221-7.

26. Gocmen A, Kucukosmanoglu O, Kiper N, Karaduman A, Ozcelik U. Yellow nail syndrome in a 10-year-old girl. Turk J Pediatr 1997;39:105-9.

27.Sacco O, Fregonese B, Marino CE, Mattioli G, Gambini C, Rossi GA. Yellow nail syndrome and bilateral cystic lung disease. Pediatr Pulmonol 1998;26:429-33.

28.Lambert EM, Dziura J, Kauls L, Mercurio M, Antaya RJ. Yellow nail syndrome in three siblings: a randomized double-blind trial of topical vitamin E. Pediatr Dermatol 2006;23(4):390-5.

29.Douri T. Yellow nails syndrome in two siblings. Dermatol Online J 2008;14(9):7.

30.Elmariah SB, Ubriani RR, Kovich O. Yellow nail syndrome. Dermatol Online J 2008;14:15-7.

31.Razi E. Familial yellow nail syndrome. Dermatol Online J 2006;12(2): 15 .

32. Wells GC. Yellow nail syndrome with familial primary hypoplasia of lymphatics, manifest late in life. Proc R Soc Med 1966;59:447.

33. Iheonunekwu N, Adedayo O, Clare A, Cummings C. Yellow nail syndrome in a medical clinic. West Indian Med J 2011;60(1):99-101.

34.Nanda S, Dorville F. Yellow nail syndrome. CMAJ 2009; 181:614.

35.Thomas PS, Sidhu B. Yellow nail syndrome and bronchial carcinoma. Chest 1987;92:121.

36.Iqbal M, Rossoff LJ, Marzouk KA, Steinberg HN. Yellow nail syndrome: resolution of yellow nails after successful treatment of breast cancer. Chest 2000;117:1516-8.

37.Valiyaparambath $\mathrm{N}$, Reid D. Yellow nail syndrome in association with renal cell carcinoma in an elderly patient. Age Ageing 2010;39:513-4.

38.D Souza MF, Mahon WE. Generalized lymphoedema with yellow nails, pleural effusions, and macroglobulinemia. Proc R Soc Med 1970;63:456.

39.Siegelman SS, Heckman BH, Hasson J. Lymphedema, pleural effusions and yellow nails: associated immunologic deficiency. Dis Chest 1969;56:114-7.

40.Scher RK. Acquired immunodeficiency syndrome and yellow nails. J Am Acad Dermatol 1988;18(4 Pt 1):758-9.

41.Dilley JJ, Kierland RR, Randall RV, Shick RM. Primary lymphedema associated with yellow nails and pleural effusions. JAMA 1968;204:670-3.

42.Marks R, Ellis JP. Yellow nails. A report of six cases. Arch Dermatol 1970;102:619-23.

43. Mattingly PC, Bossingham DH. Yellow nail syndrome in rheumatoid arthritis: report of three cases. Ann Rheum Dis 1979;38:475-8.

44.Nakielna EM, Wilson J, Ballon HS. Yellow-nail syndrome: report of three cases. Can Med Assoc J 1976;115:46-8.

45.Gubinelli E, Fiorentini S, Cocuroccia B, Girolomoni G. Yellow nail syndrome associated with sleep apnoea. J Eur Acad Dermatol Venereol 2005;19:650-1.

46.Danenberg HD, Eliashar R, Flusser G, RosenmannE, ChajekShaul T. Yellow nail syndrome and xanthogranulomatous pyelonephritis. Postgrad Med J 1995;71:110-1.

47.Cockram GS, Richards P. Yellow nail and nephrotic syndrome. Br J Dermatol 1979;101:707-9.

48.Benaixa JP, Garcia-Morillo JS, Esteban F, Gonzales-Perez JM. A syndrome of yellow nails: a case associated with Mycobacterium tuberculosis. Rev Clin Esp 2006;206:536-8.

49.Scott J. Cardiac infarction and yellow nail syndrome. Proc R Soc Med 1974;67:323.

50. Wakasa M, Imaizumi T, Suyama A, Takeshita A, Nakamura M. Yellow nail syndrome associated with chronic pericardial effusion. Chest 1987;92:366-7.

51.Ilchyshyn A, Vickers CF. Yellow nail syndrome associated with penicillamine therapy. Acta Derm Venereol 1983;63:554-5.

52.Lehuede G, Toussirot E, Despaux J, Michel F, Wendling D. Yellow nail syndrome associated with thiol compound therapy. Joint Bone Spine 2002;69:406-8.

53.Guin JD, Elleman JH. Yellow nail syndrome: possible association with malignancy. Arch Dermatol 1979;115:734-5.

54.Cimini C, Giunta R, Utili R, Durante-Mangoni E. Yellow nail syndrome as a cause of unexplained edema. Monaldi Arch Chest Dis 2009;71(4):176-9.

55.Luyten C, André J, Walraevens C, De Doncker P. Yellow nail syndrome and onychomycosis. Experience with itraconazole pulse therapy combined with vitamin E. Dermatology 1996;192:406-8.

56. Norton L. Further observations on the yellow nail syndrome with therapeutic effects of oral alpha-tocopherol. Cutis 1985;36:457-62. 


\section{Sindrom žutih noktiju - prikaz slučaja}

\section{Sažetak}

Uvod. Yellow nail syndrom (YNS), sindrom žutih noktiju, retka je bolest nerazjašnjene etiologije. Nokti mogu biti zahvaćeni svi ili samo pojedini. Iako postoji podatak da 1/3 bolesnika ima samo dve komponente sindroma, klasična klinička slika YNS opisuje se kao trijada koju karakterišu: žuti nokti, limfedem na jednom ili više mesta i hronična respiratorna bolest (bronhitis, bronhiektazije, rinosinuzitis). Limfedem može biti periferan (donji udovi ili šake), ili facijalan, laringealan, u vidu pleuralne efuzije i ascitesa, retko univerzalan: respiratorni poremećaji: sinuzitis, rekurentne pneumonije, hronični bronhitis, bronhiektazije, pleuralna efuzija.

Smatra se da YNS nastaje usled limfatične abnormalnosti, bilo anatomske (utvrđene samo kod malog broja obolelih koji su imali kongenitalne abnormalnosti) ili funkcionalne - sa povećanom mikrovaskularnom permeabilnošću. Redukovana limfna drenaža može izazvati periferni edem ili pleuralnu efuziju.

Prikaz slučaja. Ženska osoba stara 47 godina, po zanimanju tekstilna radnica, izjavila je u anamnezi da su joj se prve promene na noktima javile u 40 . godini života. Nokti su prestali da rastu, postali tamnije prebojeni. Pod terapijom antimikoticima došlo je navodno do poboljšanja. Dve godine kasnije, u 42. godini, imala je upalu pluća a od 43 . godine života hronični opstruktivni bronhitis. Od tada se razvio edem obeju nogu, izražen naročito ujutro, praćen trnjenjem prstiju. Od njene 45. godine, poslednje dve godine, svi nokti su postali izmenjene boje, žuti do žutosivi, zadebljali, uraslih ivica, bolni; pacijentkinja ima utisak da ne rastu. Zbog otoka nogu lečena je na Institutu za reumatologiju u Beogradu pod dijagnozom: poliartralgija i obostrani edem talokruralnih zglobova. U porodici nije bilo obolelih srodnika. Prilikom dermatološkog pregleda uočeno je da su svi nokti (i na rukama i na nogama) intenzivno žuto do žućkastosivo prebojeni, nokatne ploče zadebljale, odignute, bez lunule i kutikule, lateralne strane urasle u perionihijum (izgled pincete), što je bilo praćeno bolom (slike 1 i 2). Potkolenice, skočni zglobovi i stopala bili su edematozni: edem elastičan, boja kože neizmenjena (Slika 3).

Relevantne laboratorijske analize bile su u granicama referentnih vrednosti. Kolorni dopler dupleks ultrazvučni pregled vena i arterija donjih ekstremiteta, rendgenski snimak pluća i srca, kao i perfuziona scintigrafija pluća bili su u referalnim granicama. Spirometrijom je utvrđena laka opstruktivna insuficijencija plućne ventilacije. Bronhoprovokativni test sa metaholinom je bio negativan. Alergološkim testom uboda utvrđena je preosetljivost na polen trava i tekstilnu prašinu. Pulmolog je na osnovu sprovedenih ispitivanja postavio dijagnozu hroničnog opstruktivnog bronhitisa i bronhijalne astme, a specijalista za bolesti uva, grla i nosa, utvrdio je kod pacijentkinje prisustvo hroničnog rinitisa i bilateralne nazalne polipoze.

Terapija je ciljano podrazumevala vitamin E u vidu kapsula u dozi od $200 \mathrm{mg}$ triput dnevno, i u vidu aplikacije rastvora vitamina $\mathrm{E}$ i $\mathrm{AD}$ u ulju. Posle nekoliko meseci lečenja, došlo je do poboljšanja tako što su nokti počeli da rastu; proksimalni delovi nokatnih ploča dobili su normalnu boju; lunula je postala vidljiva. Nokatne ploče ruku i nogu su na kontrolnom pregledu, obavljenom posle 15 meseci primene terapije, bile žućkasto prebojene u distalnim delovima, dok su proksimalni delovi nokatnih ploča bili normalnog izgleda i boje (slike 4 i 5); potkolenice, skočni zglobovi i stopala su bili uvećanog obima zbog limfedema (Slika 6).

Diskusija. Do 2004. godine, opisano je 150 slučajeva sindroma žutih noktiju, do 2014. oko 200 slučajeva, što potvrđuje navod da se bolest retko javlja. Sindrom može početi u periodu od rođenja do kasnog životnog doba. U literaturi se navode podaci da se bolest češće javlja kod žena, te da je odnos polova 1,6:1 u korist žena, dok su rezultati pojedinih autora ukazali na odnos polova 1,2: 1 u korist muškaraca. U svetskoj literaturi objavljen je samo mali broj slučajeva sindroma kod dece; opisana je i kongenitalna pojava bolesti.

$\mathrm{U}$ ispitivanjima novijeg datuma, limfedem je registrovan kod svih bolesnika, promene na noktima kod $85,6 \%$, a pleuralna efuzija u $68,3 \%$, dok su u 
ispitivanjima drugih autora promene na noktima registrovane kod $89 \%$ bolesnika, limfedem kod $80 \%$, a respiratorne bolesti kod 63\%. U literaturi je objavljen slučaj devojčice koja je imala limfedem i pleuralnu efuziju bez promena na noktima, dečaka samo sa promenama na noktima kao i bolesnice koja je od detinjstva imala žute nokte bez limfedema, a post partum je nastala masivna pleuralna efuzija.

Naša pacijentkinja je imala klasičnu trijadu, promene na noktima, limfedem i respiratornu bolest. Promene na noktima inače mogu da prethode drugim simptomima, kao u našem slučaju, ili da se javljaju istovremeno, ili kasnije. Svi nokti su zahvaćeni u samo $10 \%$ slučajeva, a rast noktiju je usporen. Kod naše bolesnice su promene na noktima počele pre drugih manifestacija trijade, ali su se kompletno razvile kasnije.

$\mathrm{U}$ patogenezi oboljenja, postoje stavovi da je sindrom žutih noktiju nasledna bolest, sa autozomno dominantnim načinom nasleđivanja. Zbog retkih familijarnih slučajeva, prihvaćena je hipoteza da to nije primarno genetska bolest, već da je stečeno oboljenje. Može biti idiopatska ili sekundarna u okviru sistemskih bolesti, ili posledica neželjenih efekata lekova. Pretpostavka je da su hipoplastični ili deficijentni limfatični sudovi uzrok sindroma žutih noktiju; postji i hipoteza da su kliničke manifestacije rezultat primarne stromalne skleroze, a njen rezultat može biti limfna opstrukcija. Limfangiografija je demonstrirala anatomski defekt $u$ broju i veličini limfatične vaskulature kod nekih, ali ne svih pacijenata, kako je već ranije navedeno. Reverzibilnost sindroma žutih noktiju i nedostatak demonstriranja anatomskih defekata kod svakog pacijenta ukazuju na to da se pre može raditi o funkcionalnoj nego anatomskoj malformaciji. Pretpostavlja se da je respiratorna komponenta bolesti izazvana ili hipoplazijom limfnog sistema ili imunodeficijencijom. Kombinovana imunodeficijencija može biti odgovorna za manifestaciju udružene sinopulmonalne infekcije. Opisana je udruženost sindroma žutih noktiju sa mnogim bolestima: maligne bolesti limfoprliferativne bolesti; imunodeficijentna stanja, sindrom stečene imunodeficijencije; endokrine bolesti; bolesti vezivnog tkiva; pijelonefritis, nefrotski sindrom. tuberkuloza, miokardni infarkt, perikardna efuzija, astma. Takođe je zabeležena pojava sindroma žutih noktiju posle primene natrijum-valproata, penicilinamina D i soli zlata. Sindrom žutih noktiju je za pojedine autore paraneoplazijski sindrom.

Dijagnoza se postavlja na osnovu kliničke slike, i to prisustva najmanje dva od tri osnovna kriterijuma: promene na noktima, limfedem i pleuralna efuzija. Najveći dijagnostički značaj ima prisustvo promena na noktima; njih treba razlikovati od promena u okviru oboljenja lihen planus kod koga nema sistemskih promena, a lokalnim nalazom dominiraju promene na površini nokatnih ploča i atrofija (naročito vidljiva na noktima na rukama), koja nije prisutna u sindromu žutih noktiju. Pojavu žutih noktiju u hipotiroidizmu i kod osoba sa sidom (AIDS - eng. acquired immune deficiency syndrome) neki smatraju isključivo posledicom usporenog rasta nokatne ploče. Diferencijalnodijagnostički treba razlikovati sistemske edeme, kao i dugotrajne pleuralne efuzije kod pacijenata sa bronhiektazijama i sinuzitisom.

U lečenju promena na noktima, preporučuje se: intradermalno unošenje triamcinolon acetonida, lokalna aplikacija vitamina E u DMSO (dimethyl sulphoxide), oralno vitamin $\mathrm{E}$ u dnevnoj dozi od 400 do 800 internacionalnih jedinica u toku 18 meseci i oralno cink-sulfat u dozi od $300 \mathrm{mg} / \mathrm{dan}$ u toku dve godine, po potrebi u kombinaciji sa antimikoticima. Itrakonazol ubrzava longitudinalni rast nokatnih ploča. Pretpostavljeni mehanizam povoljnog dejstva vitamina E zasniva se na njegovim antioksidantnim mogućnostima in vivo.

Tok oboljenja je generalno benigan i primenjenom terapijom mogu da se kontrolišu kliničke manifestacije. U pojedinim slučajevima, čak kod $30 \%$ pacijenata, može doći i do spontanog izlečenja.

Zaključak. Prikazan je slučaj retkog sindroma žutih noktiju u kome su svi nokti bili zahvaćeni uz prisustvo hroničnog opstruktivnog oboljenja pluća i edema obe potkolenice i povoljnim dgovorom na sistemsku i lokalnu terapiju vitaminom E.

Ključne reči: Sindrom žutih noktiju; Limfedem; Hronični bronhitis; Astma; Vitamin E; Ishod lečenja; Prikazi slučajeva 